\title{
Episodic fluctuation in plasma testosterone and dihydro- testosterone in male ferrets during the breeding season
}

\author{
Donald Rieger and Bruce D. Murphy \\ Department of Biology, University of Saskatchewan, Saskatoon, Canada S7N OWO
}

In a number of species, including rats and mice (Bartke, Steele, Musto \& Caldwell, 1973), bulls (Katangole, Naftolin \& Short, 1971), and rams (Purvis, Illius \& Haynes, 1974), there is evidence of episodic fluctuation of circulating levels of testosterone. It has generally been concluded that testosterone is released from the testis in a pulsatile fashion, temporally related to the episodic release of LH (Katangole et al., 1971; Moor \& YoungLai, 1975).

Studies of the annual reproductive cycle in the ferret (Neal, Murphy, Moger \& Oliphant, 1977) and of the response of the ferret testis to LH (Neal \& Murphy, 1977) indicate plasma concentrations of testosterone, in excess of those observed in most continuous breeders, which are secreted episodically, particularly during the breeding season. Dihydrotestosterone (DHT) is believed to be the active androgen in mammalian target tissues (Mainwaring, 1975). Preliminary experiments (unpublished) have shown that DHT comprises approximately $10 \%$ of the sum of testosterone and DHT in the ferret during the early breeding season and that peripheral levels were in excess of those reported in many other species, including the dog (Tremblay et al., 1972) and man (Fiorelli et al., 1976).

The present study was therefore an investigation of (1) the relationship between testosterone and DHT concentrations in the plasma of the ferret, and (2) whether these hormones fiuctuated episodically late in the breeding season.

\section{Methods and results}

The 7 mature male ferrets used (from the University animal colony or from Dr John Gorham, USDA, Washington State University, Pullman, Washington) had been maintained for more than 1 year in outdoor cages in natural photoperiods. Experiments were performed in early July (breeding season begins in March). Animals were brought into the laboratory on the morning of the experiment. Under halothane (Somnothane: Hoechst) in oxygen anaesthesia, catheters were placed in the right jugular vein between 13.00 and $18.00 \mathrm{~h}$. At the same time the thoracic region of each animal was enclosed in a plaster cast to immobilize the catheter and prevent its removal by the animal. Ferrets were conscious within 10 min after completion of surgical procedure and remained so throughout the experiment. At $19.00 \mathrm{~h}$, and hourly thereafter for a further $26 \mathrm{~h}, 1 \mathrm{ml}$ samples of whole blood were withdrawn into syringes containing heparin. Samples were centrifuged, and the plasma was frozen at $-20^{\circ} \mathrm{C}$ until analysis. Red blood cells from each sample were resuspended in heparinized sterile saline and reinjected after removal of the subsequent sample. Sampling took place at low light intensity after dark $(22.30 \mathrm{~h})$ and the animals were then kept in a box which excluded most artificial light during the night phase of the experiment.

Aliquots of $100 \mu \mathrm{l}$ plasma were extracted twice with petroleum ether : benzene $(5: 2 \mathrm{v} / \mathrm{v})$. The dried residues were then dissolved in $1 \mathrm{ml}$ iso-octane, and testosterone and DHT were separated on $5 \mathrm{ml}$ celite columns by a procedure modified from that described by Coyotupa, Parlow \& Abraham (1972). DHT was eluted with $4 \mathrm{ml} \mathrm{10 \% (v/v)} \mathrm{ethyl} \mathrm{acetate} \mathrm{in} \mathrm{iso-octane.} \mathrm{Eluents} \mathrm{were} \mathrm{dried} \mathrm{under}$ filtered air and dissolved in $1 \mathrm{ml}$ assay buffer. Efficiency of separation was tested by means of addition of tritiated testosterone, DHT, or both to tubes containing $1 \mathrm{ml}$ iso-octane. There was less than $2 \%$ overlap between testosterone and DHT in four trials of the chromatography system. Recovery of tracer added to each sample varied from 55-100\% for testosterone and $48-95 \%$ for DHT. The radioimmunoassays were carried out as described for testosterone by Moger \& Armstrong (1974) 
and Neal \& Murphy (1977) by using antiserum S-741 No. 2 (Coyotupa et al., 1972). The intra-assay coefficients of variance were 3-9\% for testosterone and $2-8 \%$ for DHT; interassay coefficients of variance were 18 and $19 \%$ respectively. Addition of $2.5,5$ and $10 \mathrm{ng}$ authentic testosterone $/ \mathrm{ml}$ and 1 , 2.5 and $5 \mathrm{ng}$ authentic DHT/ml to plasma from 4 anoestrous female ferrets gave values of $2.25 \pm 0.24$, $4.79 \pm 0.23$ and $9.25 \pm 0.77 \mathrm{ng}$ testosterone/ml, respectively, and $0.44 \pm 0.16,1.99 \pm 0.46$ and $6.44 \pm 0.74 \mathrm{ng} \mathrm{DHT} / \mathrm{ml}$ after correction for procedural loss. Sensitivity was $10 \mathrm{pg} /$ tube for both assays.

One-way analysis of variance, considering each sample time as a treatment, was performed on the results for testosterone, DHT and the sum of the two hormones. Peaks and troughs were identified by comparisons between individual means with the least significance difference test.

All animals survived and appeared unaffected by the treatment. Concentrations of testosterone in each animal varied from 2.3 to $25 \mathrm{ng} / \mathrm{ml}$; mean values ranged from $6 \mathrm{ng} / \mathrm{ml}$ to approximately 15 $\mathrm{ng} / \mathrm{ml}$ (Text-fig. 1a). Significant variation in plasma testosterone occurred during the $26 \mathrm{~h}$ period $(P<0.05)$ and 3 peaks were identified at $22.00,06.00$ and $11.00 \mathrm{~h}(P<0.05)$. A peak approaching significance was obtained at the second $19.00 \mathrm{~h}$ sample $(0 \cdot 1>P>0.05)$; elevation also occurred at the first $19.00 \mathrm{~h}$ sample but individual statistical comparisons were not made because there was no value preceding this mean. Variability at the troughs appeared to be lower than at peak times.

As shown in Text-fig. 1(b) the range of individual DHT values was lower than that for testosterone, being 0.9 to $11.8 \mathrm{ng} / \mathrm{ml}$ (means $6.6-2.5 \mathrm{ng} / \mathrm{ml}$ ). There was a significant variation in this hormone with
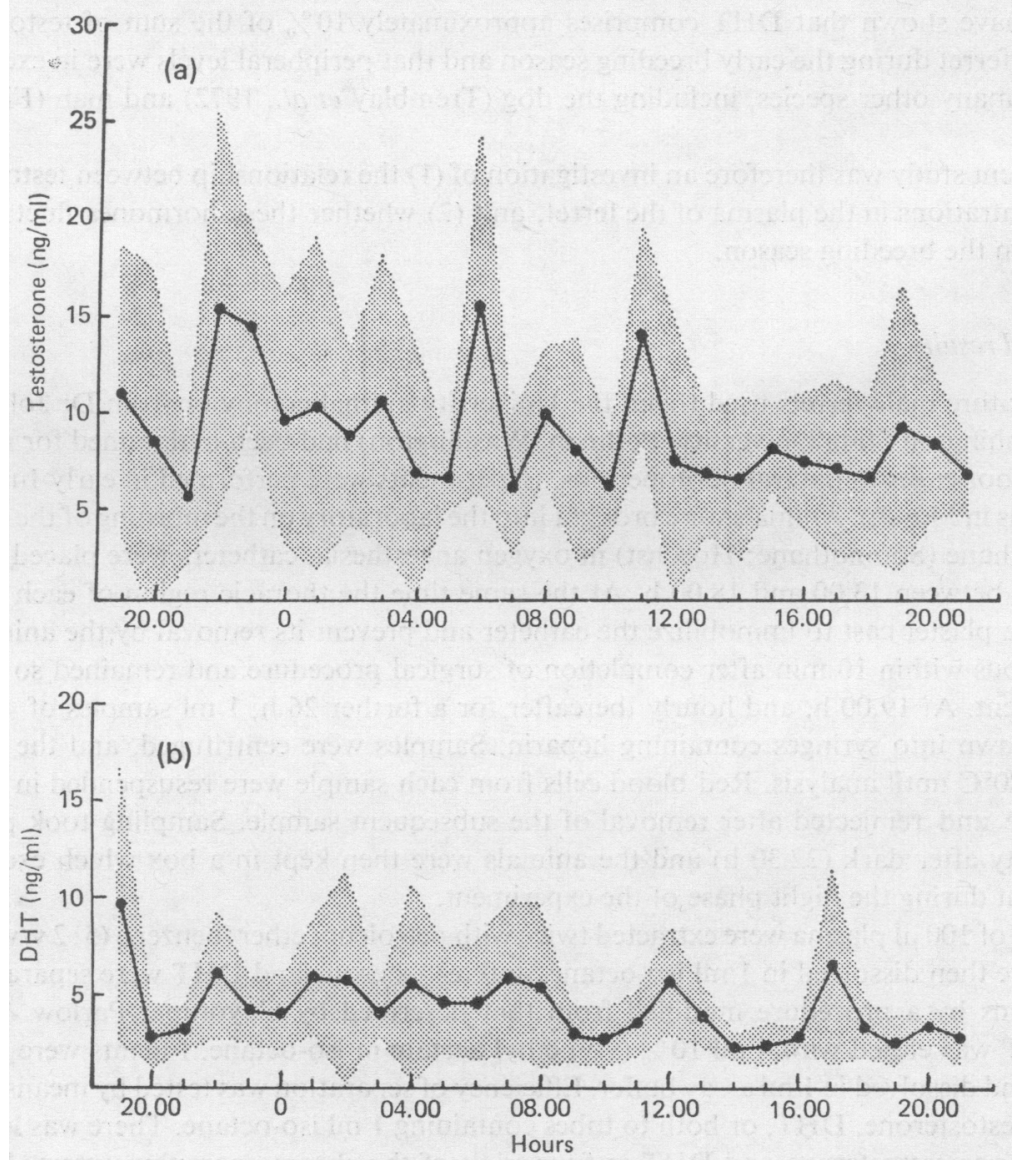

Text-fig. 1. Mean concentrations of plasma (a) testosterone and (b) 5 $\alpha$-dihydrotestosterone in 7 male ferrets during a $26 \mathrm{~h}$ period late in the breeding season. Confidence limits $(95 \%)$ are represented by the shaded area. 
time $(P<0.01)$ and peaks were noted at $22.00,12.00$ and $17.00 \mathrm{~h}(P<0.05)$. The peak at $07.00 \mathrm{~h}$ was not significantly different from the preceding lower values but was different $(P>0.05)$ from the trough which followed.

Correlation coefficients were determined between each testosterone and corresponding DHT value, and for each testosterone and subsequent DHT value 1, 2 or $3 \mathrm{~h}$ later. No significant correlations could be found.

\section{Discussion}

The results of this study confirm the presence of an episodic pattern of androgen secretion in male ferrets as suggested previously (Neal \& Murphy, 1977). Samples were taken at a time during the annual breeding cycle of male ferrets after testosterone values had peaked and were beginning to decline. The mean peak concentrations for the sum of testosterone and DHT in the present experiment were lower than those previously determined for July (Neal et al., 1977). The reasons for this are not evident, but probably do not reside in the assay system because the plasma samples used as interassay standards in both experiments gave similar results.

There were three statistically recognizable and synchronous peaks of testosterone and DHT in a $26 \mathrm{~h}$ period when all animals were considered together. The duration of the peaks was $1-4 \mathrm{~h}$, as reported for individual rabbits (Moor \& YoungLai, 1975). Four peaks of testosterone/24 h were described for individual rams by Purvis et al. (1974), but synchrony of episodic secretion has not been previously reported. This synchrony is presumed to reside in synchronous diurnal rhythms of LH secretion. The magnitude of difference in individual peaks and troughs was much greater than could be expected from preliminary experiments on animals during the early part of the breeding season (Neal \& Murphy, 1977). It is possible that seasonal regression in the male ferret is first manifest as shortening of secretory episodes. In seasonally breeding rams, variables which fluctuate between breeding and non-breeding seasons include frequency, duration and amplitude of LH and testoterone peaks (Lincoln, 1976).

The mean ratios of testosterone to DHT ranged from approximately 1 to 4 . The ratio of DHT to testosterone in ferret plasma is from 2 to 12 times greater than that observed in male dogs (Folman, Haltmeyer \& Eik-Nes, 1972; Tremblay et al., 1972) and as much as 10 times greater than that reported for men (Fiorelli et al., 1976). The absence of recognizable correlations between testosterone and DHT from the same sample or testosterone with DHT from subsequent samples suggests that DHT is not released from the testis synchronously with testosterone.

We thank Miss Jane Spencer for technical assistance, and Mr Alex Campbell for preparation of the figures. This study was supported by grant No. A9743 to B.D.M. from the National Research Council of Canada.

\section{References}

Bartke, F., Steele, E., Musto, N. \& Caldwell, B.V. (1973) Fluctuation in plasma testosterone levels in adult male rats and mice. Endocrinology 92, 12231228.

Coyotupa, J., Parlow, A.F. \& Abraham, G.E. (1972) Simultaneous radioimmunoassay of plasma testosterone and dihydrotestosterone. Analytical Letters 6, 329-340.

Fiorelli, G., Borrelli, D., Forti, G., GonNelli, P., Pazzagli, M. \& Serio, M. (1976) Simultaneous determination of androstenedione, testosterone and $5 \alpha$-dihydrotestosterone in human spermatic and peripheral venous plasma. J. Steroid Biochem. 7, 113-116.
Folman, Y., Haltmeyer, G.C. \& Eik-Nes, K.B. (1972) Production and secretion of $5 \alpha$-dihydrotestosterone by the dog testis. Am. J. Physiol. 222, 653-656.

Katongole, C.B. Naftolin, F. \& ShorT, R.V. (1971) Relationship between blood levels of luteinizing hormone and testosterone in bulls and the effects of social stimulation. $J$. Endocr. 50, 457-466.

Lincoln, G.A. (1976) Seasonal variation in the episodic secretion of luteinizing hormone and testosterone in the ram. J. Endocr. 69, 213-226.

MaINWARING, W.I.P. (1975) A review of the formation and binding of $5 \alpha$-dihydrotestosterone in the mechanism of action of androgens in the prostate of the rat and other species. J. Reprod. Fert. 44, 377-393. 
MOGER, W.H. \& ARMSTRONG, D.T. (1974) Changes in serum testosterone following acute LH treatment in mature and immature rats. Biol. Reprod. 11, 1-6.

MoOR, B.C. \& YoungLAI, E.V. (1977) Variations in peripheral levels of $\mathrm{LH}$ and testosterone in adult male rabbits. J. Reprod. Fert. 42, 259-266.

NEAL, J. \& MURPHY, B.D. (1977) Response of immature, mature nonbreeding and mature breeding ferret testis to exogenous LH stimulation. Biol. Reprod. 16, 244-248.

Neal, J., Murphy, B.D., Moger, W.H., \& Oliphant,
L.W. (1977) Reproduction in the male ferret: gonadal activity during the annual cycle; recrudescence and maturation. Biol. Reprod. (in press).

Purvis, K., Illius, A.W. \& Haynes, N.B. (1974) Plasma testosterone concentration in the ram. $J$. Endocr. 61, 241-253.

Tremblay, R.R., Forest, M.G., Shalf, J., Martel, J.G., Kowarski, A. \& Migron, C.J. (1972) Studies of the dynamics of plasma androgens and on the origin of dihydrotestosterone in dogs. Endocrinology 91, 556-561.

Received 16 May 1977 